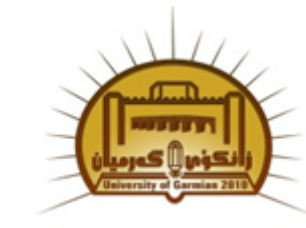

Available online at http://jgu.garmian.edu.krd

Journal of Uni versity of Garmian

https://doi.org/10.24271/jug.1964026

\title{
The Servant Heroine: Unravelling the Life of a Victorian Governess in Agnes Grey and Jane Eyre
}

\author{
Jwan Adil Mohammed \\ Department of English, College of Education, University of Garmian
}

\section{Article Info}

Received: November, 2019

Revised: December, 2019

Accepted: December, 2019

\section{Keywords}

Jane Eyre, Agnes Grey, governess, middle class

\section{Corresponding Author}

Jwan.adil@garmian.edu.krd

\begin{abstract}
Charlotte and Anne Brontë were themselves educators. Therefore it is not surprising that education plays a prominent part in their novels. This study will examine the background of the governess in the nineteenth century and its main focus will be on the governess' role in the literary works of the two Brontë sisters, Charlotte and Anne. In this piece of writing, two novels will be compared, namely Agnes Grey by Anne Brontë and Jane Eyre by Charlotte Brontë in which the two sisters featured their heroines as governesses. Moreover, the paper will describe the difficulties and struggles which arise in the novels from the position of a governess. In addition, it will also examine the possible reasons which made Jane and Anne decide to take the role of governess and how the two heroines, Jane and Anne, saw themselves in that role. Finally, this study will aim to shed light on the significant role of the governess in the shaping of the story through these novels. (Harvard style has been used).
\end{abstract}

\section{Introduction}

\section{The Background of the Governess}

The governess is considered as a familiar figure in the Victorian novel. "A governess novel features a governess heroine not necessarily a faultless or particularly splendid character, but a protagonist on whom the narrative is centred and with whom the reader's sympathy lies" (Lecaros: 2005). She serves as a strong female figure and main protagonist. Being a governess was one of the few career paths open to an educated middle class woman in the nineteenthcentury. After the 1780s, an army of women lived in other people's houses working as governesses especially middle class women. "She leaves her home and goes out into the world alone. Admittedly, the governess lives and works within a domestic sphere, but living with strangers she is not altogether a part of it" (Lecaros: 2005). It was typical and socially acceptable for single middle-class women to become governesses in order to support themselves and their families, and to maintain their social status. This entailed having to leave their own homes to care for other people's houses and their children. As a governess, there were certain roles that she was expected to follow. Some of which were well-defined whereas some were poorly defined and vague.

A key factor to be mentioned is that her most important responsibility as a governess was to educate the children. To find a respectable position as 
a governess it was necessary to possess a wide range of skills and knowledge which the society thought to be necessary for a woman. She must be able to educate her pupils in academic areas such as geography, foreign languages, playing the piano, drawing, astronomy and basics from English history and literature:

For the most part, governesses taught the 'accomplishments' - subjects regarded as useful to middle and upper-class girls, such as music, French, drawing and needlework - but often they had to teach subjects - geography, arithmetic, history - about which they knew little themselves (Tucker 1999, p. 203).

By the $1850 \mathrm{~s}$ there were more than 21,000 governesses in Britain. This yields evidence that this job was popular during the Victorian period. Due to the rise of the middle class, more people in the society were able to take on a governess. Obviously, to have a governess was in the Victorian period one of the ways how to show that the family was well-off. Hiring a governess was seen as a status symbol, because this meant that the mother can afford to be a woman of leisure, no longer responsible for the education of her children and other domestic affairs usually placed on the shoulders of the matriarch. It was known that because a governess belongs to the middle class, she was neither a servant nor an equal to her employers. Thus, she was above a servant, yet below her employers. This places her in a position which commands respect to a certain extent while remaining to be subservient to her employers. For Peterson, "the governess had no social position worthy of attention" (Peterson 1970, p. 8). No doubt, the job entails a large amount of responsibility to ensure a functioning house of a family that is not even her own.

During the beginning of the nineteenth century, the governess began to appear in a peripheral role as a character in literature, exemplified by Jane Austen's novel Emma. In this novel, there are two governesses, Miss Taylor, who was the first one and Jane Fairfax who was the second one. Emma's first governess, Miss Taylor, was fortunate enough to be treated like a member of the family (Martin 1998, p. 242). No one can ignore the fact that she was one of the few to make closer to the $£ 200$ per year, an amount significantly larger than the average of $£ 20$ pounds per year that most governesses earn. She married $\mathrm{Mr}$
Weston, a man of wealth who had dramatically elevated her social and economic stature from her job as governess. On the other side, Jane Fairfax was afraid from being a governess since she thought that life as a governess would not be worth living, as she said "retire from all the pleasures of life, of rational intercourse, equal society, peace and hope, to penance and mortification for ever" (Austen 1980, p. 129). The language here, suggests that this job was not preferable for women since this speech by Austen shows the dark view of her regard for the governess' life.

Concerning the Brontës, it is worth mentioning that they drew inspiration for their novels from their lives and experiences and the depiction of governesses is probably one of the most realistic features in Anne's and Charlotte's novels. It is known that the sisters did not have positive feelings towards the profession. Charlotte even wrote in one of her letters: "I hate and abhor the very thoughts of governess -ship. But I must do it" (Hinkey 1946, p. 34). Her statement confirms the main reason the women had for performing the work, as they were governesses "when financial necessity drove them to self-support" (Neff 2006, p. 159). This is true also for two main governess characters in the Brontës' novels: Agnes Grey and Jane Eyre. Both Agnes and Jane are driven to the positions by a necessity to earn enough money for living. While Jane does not have any relatives who would support her as she is an orphan and the only relative she knows about is her aunt Mrs Reed who despises her, Agnes decides to start the position because of her family's bad financial situation, but it is necessary to add that her parents do not force her to do so. On the other hand, she is aware of the fact that this is the only way to get at least a small income of her own.

Charlotte sent a letter to Mr Williams expressing her feelings as a governess by saying:

A governess's experience is frequently, indeed, bitter, but its results are precious: the mind, feeling, temper are there subjected to a discipline equally painful and priceless. I have known many who were unhappy as governess, but no one who regretted having undergone the ordeal and scarcely one whose character was not improved (Birrell 1887, p. 67).

The extract describes the common point of view of Charlotte regarding her life experience as a governess. Charlotte's language here is significant 
and shows her abilities to describe her situation of being a governess. It is worthy note that using words such as 'bitter', 'painful' on one hand and words such as 'precious', 'priceless' on the other hand are treated by Charlotte in the best way, since she linked these words to reveal the reality of being a governess. The words 'bitter' and 'precious', are contradictory, and the same with 'painful' and 'priceless', and by using them together, Charlotte clearly expressed and stated her own dissatisfaction, displeasure and disappointment with the role of governess in the society. In addition, she does not ignore the fact that by obtaining the governess's job she could improve her character and be self-independent woman. We could obviously see that in her book Jane Eyre and how at the end she becomes a successful woman and marries the man whom she loves.

\section{The Struggles which faced the Heroines after being} Governesses

A key factor to be noted is that in Jane Eyre and Agnes Grey, many struggles and difficulties occur that are a test to the character of both heroines, Jane and Agnes. These struggles have to do with the conflicts within the character of the governess. There are tensions between the power and the powerlessness of the governess and the inside yet marginal place of the governess in the household. It is worth mentioning that there were certain expectations surrounding the governess's personality in society and fiction. On the one hand society expected the governess's character to be humble, gentle and meek. At the same time, the governess required to be a figure of authority if she wanted to be able to get the children under control. It is significant that the employers give her authority in that position. But the same people expect a submissive polite governess, who teaches their children with tenderness, and who keeps the children happy and pleased. Besides having to be able to give orders, governesses also have to obey orders. This juxtaposition poses a certain tension, and this tension is obviously felt in Jane Eyre and Agnes Grey.

In Agnes Grey, the tension translates into the almost powerless figure Agnes becomes in her treatment of the children. She was obliged to deal with some problematic children, the children of Mrs Bloomfield, were spoiled so much by their parents (Regaignon 2001, p. 93). Anne Brontë illustrated through the scene the struggles and difficulties for the governess to maintain authority over the children. Agnes believed that it is wonderful to have a governess job and teach children since she was still young and could easily remember her own childhood, so she believes this will help when she is teaching children as this could be seen in this quotation:

I had but to turn from my little pupils to myself at their age, and I should know, at once, how to win their confidence and affections; how to waken the contrition of the erring; how to embolden the timid and console the afflicted; how to make Virtue practicable, Instruction desirable, and religion lovely and comprehensible. [...] To train the tender plants, and watch their buds enfolding day by day! (Brontë 1969, p. 20).

At first, she was enthusiastic and had high hopes that the children would change into better characters and would improve quickly. Agnes was quickly disappointed from teaching the children since Mrs Bloomfield's children did not see her as an authority figure. The Bloomfield household, as Agnes described, was absolutely different from the pleasant home she had come from (Regaignon 2001, p. 101). Agnes' dreams and imagination became a nightmare when she saw that her students did not obey or respect her speech. She could not punish them and the children's parents did not support her, but in contrast they criticized her for not being able to do her job well. There was not enough space to allow her to actually do her job and impart character to the children.

An example of Agnes' frustration can easily be seen in the children treat animals, especially Tom. Tom, one of her students, sets up 'traps for birds' (Brontë 1969, p. 27). This shows the inhumane disposition that the children have toward living creatures. Digby (1996, p. 224) illustrated that Tom killed animals just for the kick of having fun. Agnes tried her best to persuade Tom that hurting a small animal is unpleasant thing to do, but she failed on her attempts since the children did not listen to her and in fact, she does not have much power in the house. Agnes described her bad conditions of working as a governess since her students did not agree to do their lessons and the worst part were her employers who regarded their children as angels and refused to listen to Agnes. 
On the other hand, one can find that in Jane Eyre the difficulties for having power and influence over the students were less evident than compared to that in Agnes Grey. This is because, Jane had only one student to teach so she spent much her time teaching little Adele because she had more time than Agnes. While the case is different for Agnes since there was more than one student to teach. It is true that Adele, the daughter of a French actress, in Jane Eyre, was a problematic student, but at the same time not unmanageable (Allott 1973, p. 47). Jane thought that it was necessary to be consistent with her and that a good learning and education will develop Adele's personality through persistence and dedication. Jane spends a great deal of time teaching Adele, but has more spare time than Agnes, especially because she only has one pupil. After a period of time, Jane observes that Adele made "reasonable progress" (Brontë 2000, p. 108) and she was happy for that because at the beginning Adele was a "spoilt and indulged" (Brontë 2000, p. 108) child. Mr. Rochester serves as a ward for Adele and respects Jane's capability of teaching Adele. He told Jane that he has examined Adele's character, and observes that Jane has made great efforts in teaching Adele, and that "in a short time she has made much improvement" (Brontë 2000, p. 121).

3. The possible reasons to be governesses

In both works, Jane Eyre and Agnes Grey, one can easily discover that the Bronte sisters used much of their daily experiences and their own lives to be able to write their masterpieces. It is true that the two heroines, Jane and Agnes, had different backgrounds but they took the role of governess much the same way initially and they became governesses in their early life. However, despite the differences in their upbringing and personal background, Jane's childhood at the Reeds was unpleasant and experienced being an outsider in the family (Birrell 1887, p. 67). This is because her parents died while she was still a small child so as a result; she was obliged to live with the Reeds who were the only family she has by marriage. The consequences of such a bad childhood because of her surrogate family's maltreatment affected Jane badly. This propelled her to take a different path at Lowood School.

However, after spending eight years, six as a student and two as a teacher, Jane recognized that it is the best time to leave the school and search for more freedom. She says: 'I become tired of the routine of eight years in one afternoon. I desire liberty' (Bronte 2000, p. 85). Progressively, Jane has grown into a sensible young lady, able to think for herself and also able to act by herself. After leaving Lowood, Jane started her work at Thornfield Hall as a governess and later on she felt in love with Mr Rochester, who was her employer and a wealthy man. This kind of love affair was considered as scandalous and shame befallen the woman from a middle class background who falls in love with a man from the upper class, especially if that person is her employer (Fest 2009, p. 47). Society raises its eyebrow to such kind of relationships since this was uncommon and highly dis reputable.

It is worth mentioning that Agnes was anxious to form the beginning of her life to see more and make her own mark in the world. She says "I wish I could do something... I should like to be a governess" (Brontë 1969, p. 19). Some sad events happened in her life which obliged her to take the role of governess. Her father lost his fortune and consequently, Agnes believed that she should prove her abilities to the family by helping them in their financial problem from that point, the idea of working as a governess came to her mind since it was a preferable job for middle class women to do.

She instils in her mind the idea of self-satisfaction when she obtains the position of being entrusted in caring for children of a wealthy family and she aimed for the appreciation she would gain from her lovely family. Her family rejected strongly Agnes' decision to work as a governess. Her mother told her that she could hardly take care of herself so how the case will she be able to properly take care of others. Her sister, Marry, was astonished by the idea and said, "you a governess, Agnes! What can you be dreaming of!" (Brontë 1969, p. 19). Moreover, she stated that Agnes will live at a house of strangers and that neither she nor her mother will be able to speak or defend her there. Her father could not believe that his daughter wants to be a governess and work in such a position. He said "my little Agnes a governess!" (Brontë 1969, p. 19). No doubt, Agnes's family could not stand the idea that she wants to be a governess as we can clearly see that in their reactions and responses toward Agnes. However, Agnes asserted her decision to be a governess and she disagreed strongly with her 
family by telling them that she will try her best in this job and she will show them her capabilities in depending on herself. Agnes had many reasons in her mind which could possibly affect her to become a governess:

To go out unto the world; to enter into a new life; to act for myself; to exercise my unused faculties; to try my unknown powers; to earn my own maintenance, and something to comfort and help my father, mother and sister, besides exonerating them from the provision of my food and clothing; to show papa what his little Agnes could do (Brontë 1969, p. 18).

It is clear from the above quotation that going out and experience a new life can be partially marked as a first step towards independence. Agnes concludes that going out and depending on herself would give her a great opportunity to discover her personality and act for herself. She wants to be an independent woman and proves for her family that she is not the "helpless, thoughtless being" that her family believe her to be. In addition, she tells her family that they think she cannot depend on herself because as she said, "I always do as you bid me, I have no judgment of my own: but only try me- that is all I ask- and you shall see what I can do" (Brontë 1969, p. 18). Agnes decides to start the position because of her family's bad financial situation, but it is necessary to add that her parents do not force her to do so. On the other hand, she is aware of the fact that this is the only way to get at least a small income of her own and go out in the world to start a new experience. The development of Agnes as a character is a refreshing take on a woman driven to becoming a governess to prove herself and her set goals, facing difficulties, and finally turning out to be the epitome of a governess who commands respect, gains affection and proves that she was right in making a decision to act for herself. In other words, it was necessary to obtain a governess position if a middle class woman wants to maintain her membership within the gentry. A key factor to be noted is that there remain the high expectations of a happy ending for both characters, Jane and Agnes. This illuminates on the hopeful future that the Victorian era governess can be a heroine and surpass her position which consequently defines her entire persona. Characters such as Jane Eyre and Agnes Grey provide for different aspects and life that a governess may lead. These typically involve having a difficult beginning with her integration to the new family. But this is not the end of the road as the novels reveal a fortunate ending to their otherwise ordinary heroine. Both governesses, Jane and Agnes, in the end, are able to have a family of their own and to leave a lasting impression to the nurturing of the family they have served. If Jane and Agnes did not work as governesses in these novels, they will not marry those persons that they met throughout their job. For instance, Agnes married $\mathrm{Mr}$ Edward Weston and Jane married Mr Rochester and these happy events happened because these two girls to a large extent served as governesses. Otherwise, they may not have attained such great happiness. Their work as governesses and journey far from their homes led them to their fulfilling future. The two Brontë sisters, Charlotte and Anne, were the authority in this theme and this is primarily due to their knowledge of the topic based on personal experience and intrinsic proclivity to write elegantly through their masterfully crafted novels. It is important to state that both heroines, Jane Eyre and Agnes Grey, started their careers as governesses because both wished to see and discover more of their world. As the days passed, the two protagonists tested their personality and recognized who they really are.

\section{Conclusion}

To sum up, Agnes Grey and Jane Eyre are two nineteenth century governess novels where one could easily recognize that the governess is the central character and where a great deal of attention is paid to the intermediate position of the governess. Both novels show the readers the difficulties and challenges that the governesses faced during the nineteenth century. A woman with no fault and of a gentle birth may face hard and difficult times when she becomes a governess. Although Jane's social position as a governess is not as clear as that of Agnes, but Jane Eyre, still remains as a novel in which the position of a governess is present. Ingham (2006) believed that "it is only Agnes Grey which describes in great detail the painfully humiliating treatment that a governess such as Agnes experiences in what are represented as typical middle-class households" (Ingham 2006, p. 107). If we look at the development Agnes and Jane went through in their stories, they are very different in nature. This is partly because we do not just follow Jane as a governess, as we do with Agnes. Throughout her story, we see her 
in such differing roles as a child, student, teacher, governess, beggar, schoolteacher, heiress and finally as a wife. However, the two sisters made success in the way of presenting their story and they portrayed their heroines in the most proper way.

The Brontë sisters suffered from homesickness and loneliness. Neither Charlotte nor Emily made success in their experience as governesses. Anne was the only one among her sisters who maintained, challenged and made a great success in her job. Anne's portrayal of her heroine in the sense of the governess's role could be considered as more realistic than Charlotte's one. This is because Anne in Agnes Grey told the audience her real experience in life as a governess, while Charlotte did not marry her master in real life as she portrayed her heroine in Jane Eyre. However, in both novels, the reader can easily understand the Brontë's experience as governesses and their own views of the job.

\section{References}

Allott, M., 1973. Jane Eyre and Villette. London and Basingstoke: Macmillan Press.

Anderson, N.F., 1993. The Victorian Governess by Kathryn Hughes. Albion: A Quarterly Journal Concerned with British Studies, 25 (3). Available from: http://www.jstor.org/stable/4050913 [Accessed 25 January 2016].

Austen, E., 1980. Emma. Oxford: Oxford University Press.

Birrell, A., 1887. Life of Charlotte Bronte. London: Walter Scott.

Brontë, A., 1969. Agnes Grey. London: The Folio Society.

Brontë, C., 2000. Jane Eyre. Jane Eyre. Oxford: Oxford University Press.

Digby, A., 1996. The Victorian Governess by Kathryn Hughes. The English Historical Review, 111 (440). Available from: http://www.jstor.org/stable/577968 [Accessed 25 January 2016].

Fest, K., 2009. Angels in the house or girl power: Working women in nineteenth-century novels and contemporary chick lit. Women's studies, 38 (2009), pp. 43-62.
Hinkley, L.L.,1946. Charlotte and Emily. New York: Hastings House.

Ingham, P., 2006. The Brontes. Oxford: Oxford University Press.

Lecaros, C.W., 2005. The Victorian Governess Novel: Characteristics of the Genre. Available from: http://www.victorianweb.org/genre/wadso1.html

[Accessed 26 January 2016].

Martin, J., 1998. A Governess in the Age of Jane Austen: the journals and letters of Agnes Porter. The

Historical Review, 116 (465). Available from: http://ehr.oxfordjournals .org/content/116/465/241

[Accessed 24 January 2016].

Mitchell, S., 1994. The Victorian Governess by Kathryn Hughes. Victorian Studies, 37 (2). Available from: http://www.jstor.org/stable/3828922 [Accessed 22 January 2016].

Neef, W. F., 2006. Victorian Working Women: An Historical and Literary Study of Women in British Industries and Professions 1832-1905. Oxon: Routledge. Available from: http://books.google.com [Accessed 23 January 2016].

Peterson, M.J., 1970. The Victorian Governess: Status Incongruence in Family and Society. Victorian

Studies, 14 (1). Available from: http://www.jstor.org/stable/3826404 [Accessed 24 January 2016].

Regaignon, D.R., 2001. Instructive Sufficiency: Rereading the Governess through "Agnes Grey". Victorian Literature and Culture, 29 (1). Available from: $\quad$ http://www.jstor.org/stable/25058541 [Accessed 25 January 2016]. pp. 85-108

Tucker, H.F., 1999. A Companion to Victorian Literature and Culture. Oxford: Blackwell Publishers. Available from: http://books.google.com [Accessed 25 January 2016]. 